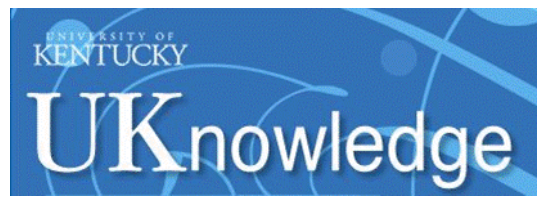

University of Kentucky

UKnowledge

Institute for the Study of Free Enterprise

Working Papers

Institute for the Study of Free Enterprise

$12-2020$

\title{
Facts and Trends Regarding Performance and Funding of K-12 in Kentucky
}

John Garen

University of Kentucky, john.garen@uky.edu

Follow this and additional works at: https://uknowledge.uky.edu/isfe_papers

Part of the Education Economics Commons, and the Elementary and Middle and Secondary Education Administration Commons

Right click to open a feedback form in a new tab to let us know how this document benefits you.

\section{Repository Citation}

Garen, John, "Facts and Trends Regarding Performance and Funding of K-12 in Kentucky" (2020). Institute for the Study of Free Enterprise Working Papers. 35.

https://uknowledge.uky.edu/isfe_papers/35

This Research Paper is brought to you for free and open access by the Institute for the Study of Free Enterprise at UKnowledge. It has been accepted for inclusion in Institute for the Study of Free Enterprise Working Papers by an authorized administrator of UKnowledge. For more information, please contact UKnowledge@lsv.uky.edu. 


\title{
Facts and Trends Regarding Performance and Funding of K-12 in Kentucky
}

\author{
John Garen
}

December 2020

Institute for the Study of Free Enterprise

Working Paper 36

\author{
University of Kentucky \\ 244 Gatton College of Business and Economics \\ Lexington, KY 40506-0034 \\ http://isfe.uky.edu/
}

\section{Gatton College of




\title{
Facts and Trends Regarding Performance and Funding of K-12 in Kentucky
}

\author{
John Garen* \\ BB\&T Professor of Economics \\ University of Kentucky
}

December 2020

\begin{abstract}
Kentucky's K-12 experienced an 80\% in increase in per pupil funds, after inflation, from 1990 to 2019. However, there have been only modest changes in its nationally-administered test scores, and no increases in the past decade. Moreover, per pupil funding seems to exceed that of all but the most exclusive private school tuition. Just over one-half of public funds goes directly to instruction and most funds to local schools come from Frankfort. Scoring on Kentucky's own student assessment tests, the K-PREP, are higher than that of the comparable nationallyadministered tests. Also, K-PREP shows improvement, while the other tests do not. About 20\% of Kentucky students fall into the lowest K-PREP score category. For African American students, it is double that percentage. Kentucky's K-12 system impedes teachers and other school personnel in devising suitable programs for the varied needs of children, and inhibits parental choice among possible alternatives. A system of robust school choice and competition enables the design of programs by teachers/schools and empowers parental choice among programs to suit their children's needs.
\end{abstract}

*During 2018 and 2019, I was part of a group of citizen volunteers that informally discussed Kentucky's K-12 finances and performance with the chair of the Kentucky Board of Education's Finance Committee. This report stems from the discussions, ideas, and work of that group. I am deeply grateful to group members for all of their efforts and insights. However, I am responsible for the content of this report. Some of the material in the report was presented to the Kentucky Board of Education on December 4, 2019, as well as in other venues. 


\section{Executive Summary}

This paper presents a series of facts and trends regarding K-12 in Kentucky, then draws some inferences and conclusions.

\section{Facts and Trends}

- $\quad$ Per-pupil funding (the total of state, local, and federal funds) rose by $80 \%$ between 1990 and 2019 after removing inflation. (Without removing inflation, it more than tripled.)

- Per pupil funding, after inflation, rose virtually every year over this time span except for the years following the Great Recession.

- National Assessment of Educational Progress (NAEP) test scores rose by small amounts since the early- to mid-1990s through 2019. Grade 4 reading rose by $4 \%$, grade 4 math by $11.1 \%$, grade 8 reading by $0.3 \%$, and grade 8 math by $8.1 \%$.

- $\quad$ NAEP scores have not risen at all in the last decade.

- Compared to a sampling of private school tuition rates, per pupil funding for Kentucky public schools exceeds that of all but the most exclusive private schools.

- In 2019, just over half (53.27\%) of total K-12 expenditure was classified as “instructional." The remaining $46.73 \%$ was spent on a variety of non-instructional uses.

- In 2018-2019, only about one-third of K-12 funding is from local sources; $55.2 \%$ is from the state and $11.1 \%$ from the federal government.

- Kentucky's student assessment test, the K-PREP, consistently shows higher scores than the comparable NAEP tests.

- K-PREP test outcomes show substantial improvement while those for NAEP and the ACT test indicate essentially no change.

- Roughly one-fifth of Kentucky students score in the lowest possible score category ("novice") for $4^{\text {th }}$ and $8^{\text {th }}$ grade reading and math. About $30 \%$ of students score in the lowest possible category on the corresponding NAEP tests, except for grade 4 math.

- The percent of African American students who score in the lowest possible category is roughly double that of students as a whole.

\section{Inferences and Conclusions}

- The high and increasing cost of K-12, coupled with its weak performance indicate the need for fundamental reform based on sound principles.

- Due to the heterogeneity of students and their needs, there is no single "best practice" that can be planned and implemented by a central authority.

- Devolving decision making regarding schools to those most knowledgeable about the school children and their circumstances enables the evolution of better-suited programs. Those with the most intimate knowledge are parents, teachers, and school personnel.

- This is attained by:

- Schools having the authority to design programs to meet the needs of their students and communities, with accountability and incentives to do it well.

- Parents having choice regarding where to send their children to school, where funding follows the student. This provides incentives to schools to offer effective programs.

- This is essentially the system of choice and competition that works well in the provision of many other goods and services. 


\section{Overarching Trends in Funding and Performance}

\section{A. The Funding of Kentucky Public Schools, 1990-2019}

In the 1989-1990 school year, per pupil funds, inclusive of state, local, and federal, for K12 was \$4,014. Adjusted for inflation and expressed in 2019 dollars, this is $\$ 7,852$. By 20182019, per pupil funding was $\$ 14,115$. Thus, taking out inflation, funding was $80 \%$ higher than in 1989-1990.

Figure 1 illustrates this. After inflation, per pupil increased virtually every year except during the time period near the Great Recession.

\section{Figure 1}

Funding for Kentucky Schools, 1990-2019

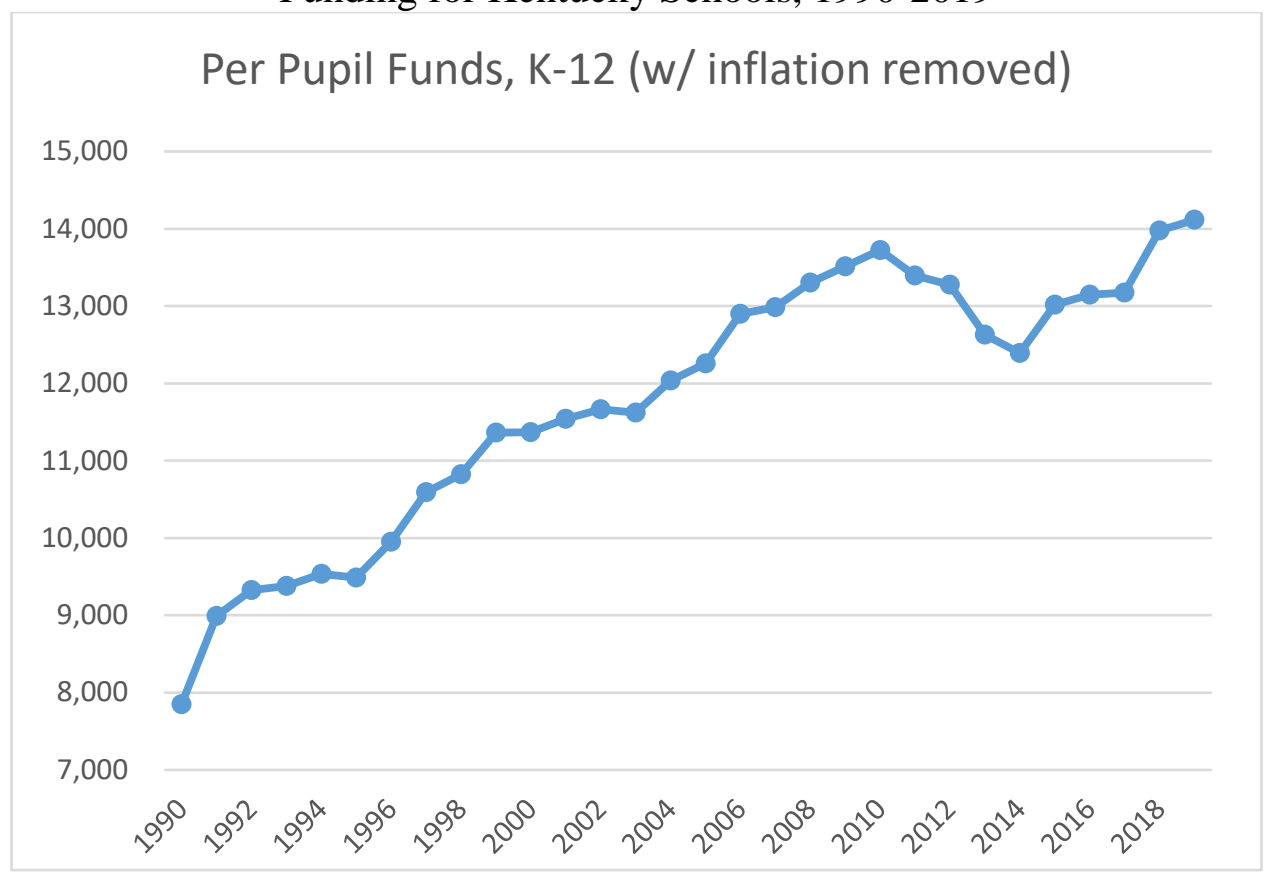

Sources: See appendix Table A1.

\section{B. Kentucky Students’ Achievement Test Score Performance}

The achievement test scores used are the National Assessment of Educational Progress (NAEP) scores for $4^{\text {th }}$ and $8^{\text {th }}$ grade reading and math. This is often referred to as the "Nation's 
Report Card.” Though the goal of education is to help attain success in life, acquiring the basic reading and math skills that these tests measure is critical preparation for this objective,

Since 2003, each of these tests has been administered in every odd year. Prior to that, they were given intermittently. Figure 2 summarizes the changes in the average score for Kentucky students from the inception of each test, as well as over the past decade. ${ }^{1}$

None of these test scores have improved in the 2009 to 2019 decade and three of the four declined. Moreover, long-term changes since the 1990s been relatively small, ranging from $0.26 \%$ to $11.1 \%$.

Figure 2

NAEP Score Changes

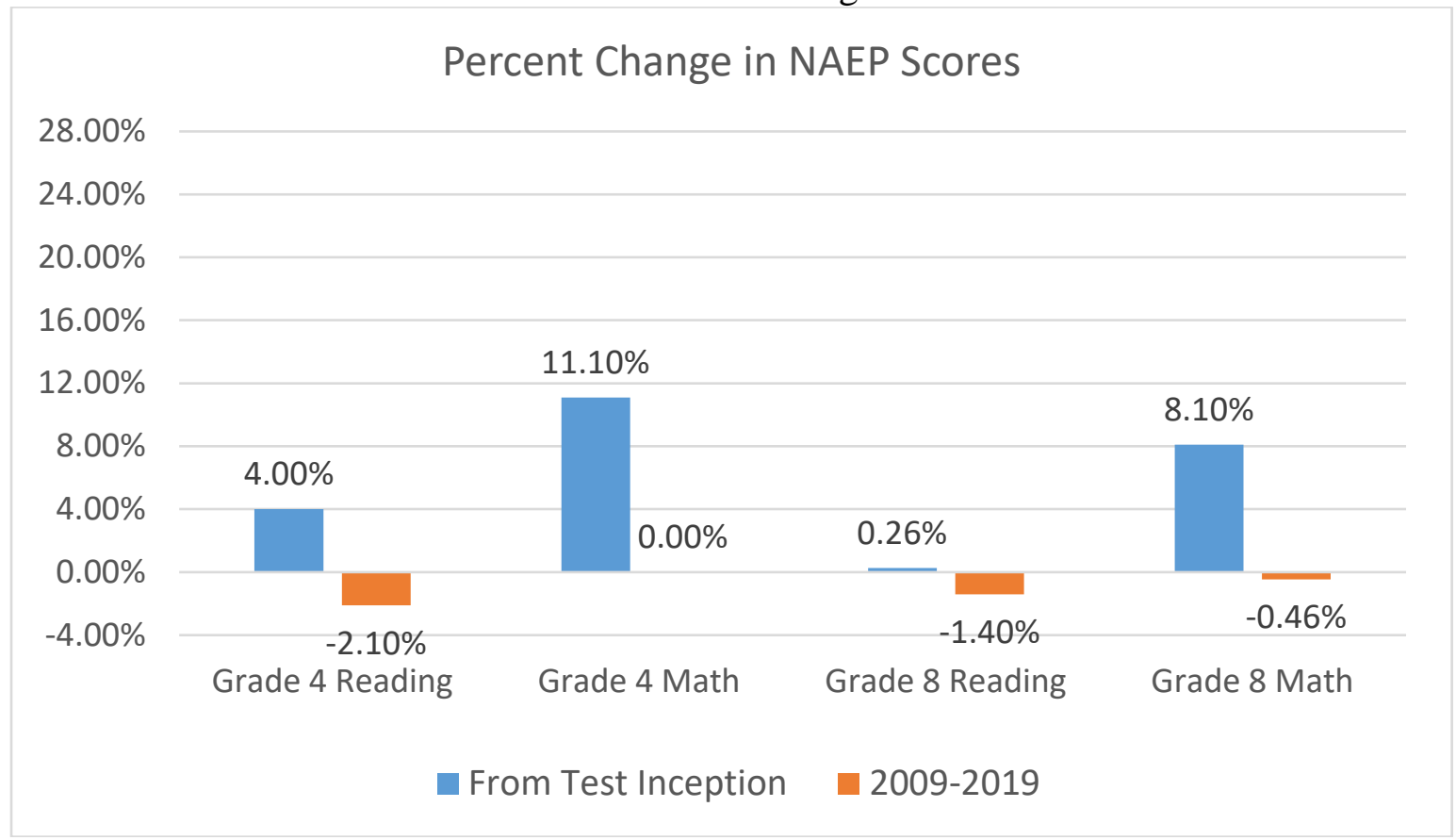

Source: See appendix Table A2.

\footnotetext{
${ }^{1}$ The grade 4 reading and math tests began in 1992. The grade 8 reading test began in 1998 and grade 8 math in 1990.
} 


\section{Illustrating the Comparison of Funding Changes to Test Score Changes}

One way to compare funding to test score changes is to plot each data series showing an index of its changes relative to a starting year. Figure 3 presents this. Both grade 4 reading and math start in 1992, $8^{\text {th }}$ grade reading and math start in 1998 and 1990, respectively, and the starting point for per pupil funding is 1990. Each year's value is expressed relative to its beginning year. Thus, each data series begins at 1.00 and subsequent values indicate the percent increase since the data began. For example, a subsequent value of 1.20 indicates a $20 \%$ increase from the starting year.

\section{Figure 3}

Per Pupil Funding and NAEP Score Changes Relative to the 1990s

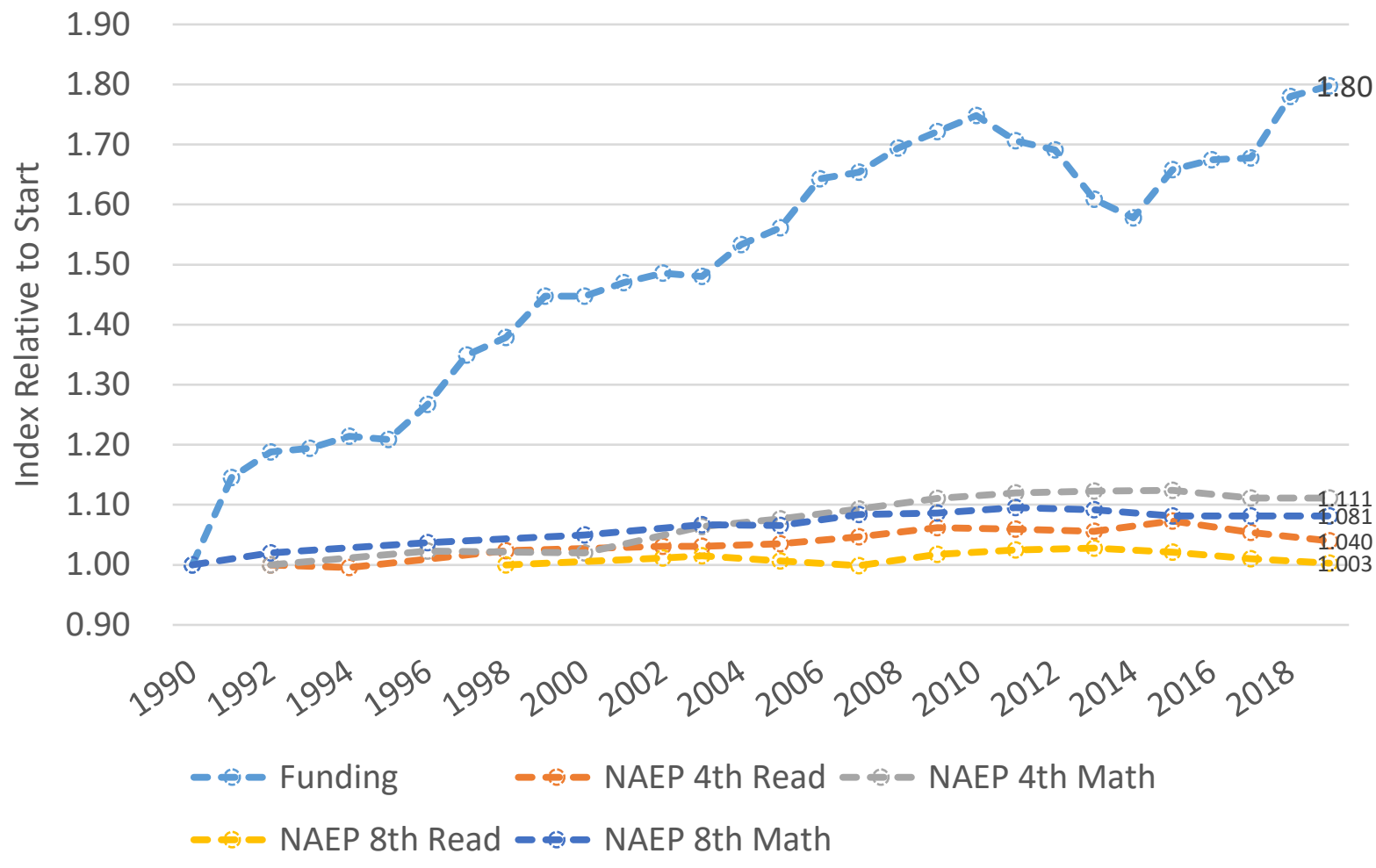

Source: Data from appendix Tables A1 and A2. 
The figure shows the time path of the index data series as well as their 2019 values. For funding (the light blue line), its 2019 value is 1.80, indicating an 80\% increase per pupil (after removing inflation) since 1990. The NAEP test score index values are much smaller, ranging from 1.003 to 1.111 . As illustrated by the figure, funding increases far outstrip any of the test score increases.

\section{Other Aspects of K-12 Funding}

\section{A. Recent Kentucky K-12 Funding Compared to Private School Tuition}

Table 1 shows per pupil funding for Kentucky schools as a whole, as well as for selected individual school districts. This is the total of state, local, and federal funding for districts during the 2018-2019 academic year. This is the latest year available from the Kentucky Department of Education's website. ${ }^{2}$

A sampling of districts with high levels of funding are shown, along with funding for the two largest school districts (Jefferson and Fayette Counties), some districts near the state average funding of $\$ 14,398$, and those at or near the bottom in funding. The highest funded district is Anchorage Independent with $\$ 24,206$ per pupil. Note that some rural districts are near the top in funding with over $\$ 20,000$ per pupil, i.e., Owsley County and Robertson County. Jefferson County, with nearly $\$ 17,000$ per pupil, has well above average funding, as does Fayette County with over $\$ 16,000$ per pupil. The least funded districts have over $\$ 12,000$ of per pupil funding, with Warren County being the lowest.

\footnotetext{
${ }^{2}$ This is the source of the some Table 1 data, as well as the other funding data: https://education.ky.gov/districts/FinRept/Pages/Fund\%20Balances,\%20Revenues\%20and\%20Expenditur es,\%20Chart\%20of\%20Accounts,\%20Indirect\%20Cost\%20Rates\%20and\%20Key\%20Financial\%20Indic ators.aspx. This also is a source for other data and is listed in appendix Table A1.
} 
Table 1

Per Pupil Funding, Selected Jurisdictions, 2018-2019

\begin{tabular}{|l|c|}
\hline Public Jurisdiction & Per Pupil Funds, 2018- 2019 \\
\hline Kentucky & $\$ 14,398$ \\
\hline Anchorage Independent & $\$ 24.206$ \\
\hline Owsley County & $\$ 21,161$ \\
\hline Robertson County & $\$ 20,086$ \\
\hline Newport Independent & $\$ 19,605$ \\
\hline Jefferson County & $\$ 16,858$ \\
\hline Wolfe County & $\$ 16,391$ \\
\hline Fayette County & $\$ 16,151$ \\
\hline Letcher County & $\$ 14,578$ \\
\hline Clark County & $\$ 14,388$ \\
\hline McCreary County & $\$ 14,311$ \\
\hline Anderson County & $\$ 12,895$ \\
\hline Oldham County & $\$ 12,645$ \\
\hline Laurel County & $\$ 12,527$ \\
\hline Warren County & $\$ 12,043$ \\
\hline
\end{tabular}

Note: Of Kentucky’s total per pupil funding, \$1,603 is accounted for by student food and transportation expenses.

For comparison purposes, Table 2 presents selected private school tuition rates. This is the primary source of funds for private schools, so can be compared to the per pupil funding levels for public schools. ${ }^{3}$ The table is broken into two parts: the upper part for elementary school rates and the lower part for high schools. This is a sampling of schools across the state and across the range of tuition costs. It is not a full sample but my judgment is that it is a good representation of private school tuition.

\footnotetext{
${ }^{3}$ Note that public K-12 funding is for the 2018-2019 academic year, while the private school tuition rates are for 2020-2021. A better comparison would be to the 2020-2021 public K-12 funding level. This would be higher than the figures reported but is not available.
} 
Table 2: Selected Private School Tuition Rates, 2020-2021

\begin{tabular}{|l|c|l|}
\hline Selected Private Schools & $\underline{\text { Tuition, 2020-21 }}$ & Comments \\
\hline Primary & & \\
\hline Christian Academy of Carrollton & $\$ 3,250$ & primary and middle school rate \\
\hline Christian Fellowship School (Benton) & $\$ 3,725$ & \\
\hline $\begin{array}{l}\text { Cornerstone Christian Academy } \\
\text { London) }\end{array}$ & $\$ 4,500$ & \\
\hline St. Joseph Academy (Walton) & $\$ 4,935$ & primary and middle school rate \\
\hline $\begin{array}{l}\text { Foundation Christian Academy } \\
\text { (Bowling Green) }\end{array}$ & $\$ 5,590$ & \\
\hline Highlands Latin School (Louisville) & $\$ 7,675$ & \\
\hline Christ the King (Lexington) & $\$ 9,795$ & $\begin{array}{l}\text { non-Catholic rate, primary and } \\
\text { middle school }\end{array}$ \\
\hline Lexington Christian Academy & $\$ 10,497$ & grade 4-5 rate \\
\hline $\begin{array}{l}\text { Northern Kentucky Montessori } \\
\text { Academy }\end{array}$ & $\$ 11,266$ & \\
\hline The Lexington School & $\$ 23,470$ & primary and middle school rate \\
\hline & & \\
\hline High School & $\$ 3,450$ & \\
\hline Christian Academy of Carrollton & $\$ 4,600$ & same rate for K-12 \\
\hline Somerset Christian School & $\$ 5,745$ & middle and high school rate \\
\hline Lexington Latin School & $\$ 5,875$ & \\
\hline $\begin{array}{l}\text { Foundation Christian Academy } \\
\text { Bowling Green) }\end{array}$ & $\$ 6,960$ & same rate for K-12 \\
\hline Frankfort Christian Academy & $\$ 8,250$ & \\
\hline Bethlehem High School (Bardstown) & $\$ 8,340$ & non-Dicoesan rate \\
\hline Newport Central Catholic High & $\$ 8,900$ & \\
\hline $\begin{array}{l}\text { Calvary Christian School } \\
\text { (Covington) }\end{array}$ & $\$ 10,600$ & middle and high school rate \\
\hline Trinity Christian (Lexington) & $\$ 25,300$ & non-Catholic rate \\
\hline Lexington Catholic High School & & \\
\hline Lexington Christian Academy & & \\
\hline St. Xavier (Louisville) & & \\
\hline Sayre School (Lexington) & & \\
\hline Soures & & \\
\hline
\end{tabular}

Sources: See websites in appendix Table A3. 
Tuition is typically much lower than the per pupil public school funding levels, and often markedly lower. The only exceptions are the tuition levels for the most exclusive private schools. High school is the most expensive level of schooling and most of the private high school rates are much lower than public per pupil funding for all levels of schools. Public schools funds do, however, include the cost of transportation and food programs for students, which was \$1,603 per pupil in 2018-2019.

\section{B. Funding for Instructional Purposes in Kentucky Public Schools}

The Kentucky Department of Education categorizes school expenditures by "instruction” expenses and a host of other categories. The Kentucky Department of Education Uniform Chart of Accounts define expenditures for instruction as: “Activities for instruction that dealing[sic] directly with the interaction between teachers and students. Teaching may be provided for students in a classroom, in another location such as a home or hospital, and in other learning situations such as those involving cocurricular activities. It may also be provided through some other approved medium, such as television, radio, computer, the Internet, multimedia, telephone, and correspondence, that is delivered inside or outside the classroom or in other teacher-student settings. Included here are the activities of aides or classroom assistants of any type who assist in the instructional process." ${ }^{4}$

Figure 4 depicts the percent of total K-12 expenditure spent on "instruction.” As seen, just over half, 53.27\%, is utilized on instruction. Appendix Table A4 has more detail. The remaining $46.73 \%$ is spread among many categories, where the major ones are student support services, instructional staff support services, district administration, school administration, business support service, plant operations, pupil transportation, food services, and debt service.

4https:/education.ky.gov/districts/FinRept/Documents/KDE\%20Chart\%20of\%20Account\%20Segment\% 20Descriptions\%20ADA\%20(FY1920).pdf. 


\section{Figure 4}

K-12 Expenditure Percentages, 2018-2019

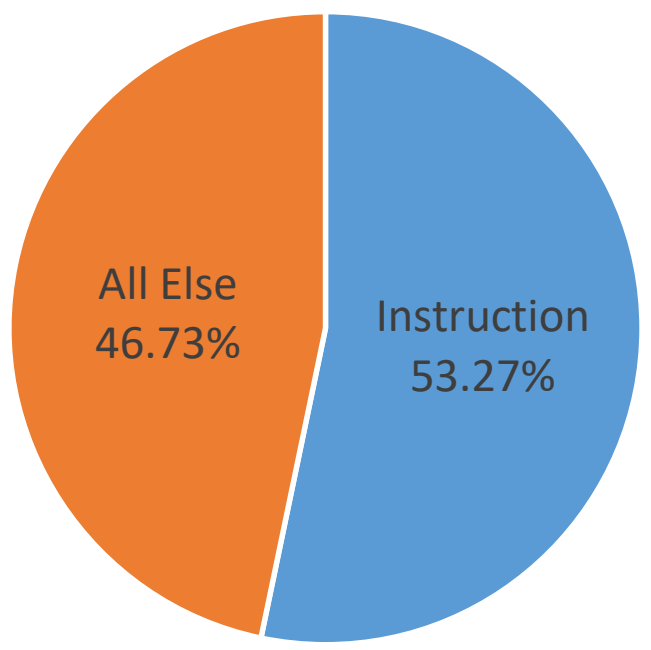

Source: See appendix Table A4.

\section{Sources of Funds: State, Local, and Federal}

Figure 5 shows the source of funds for Kentucky's public schools for 2018-2019. Panel (a) is the percent from each source and panel (b) is the total funding amounts. As is seen, local districts provide about one-third of school funding, with the other two-thirds from the state and federal governments. State government is the dominant source of funds, accounting for $55.2 \%$.

Figure 5: State, Local, and Federal Funds, 2018-2019

(a) Fund Sources, Percent

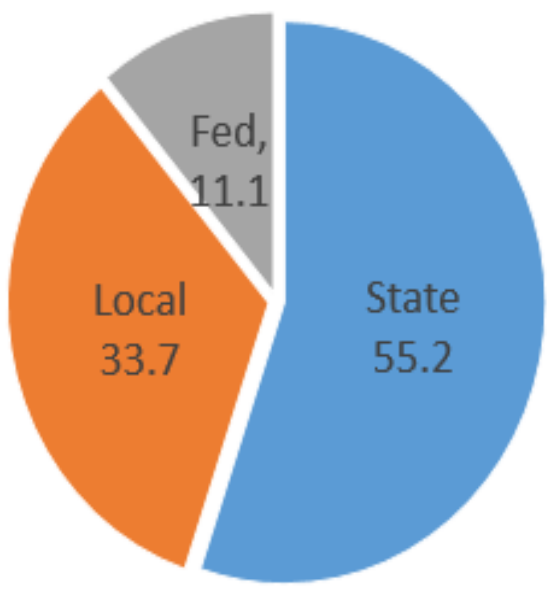

(b) Fund Sources, Totals

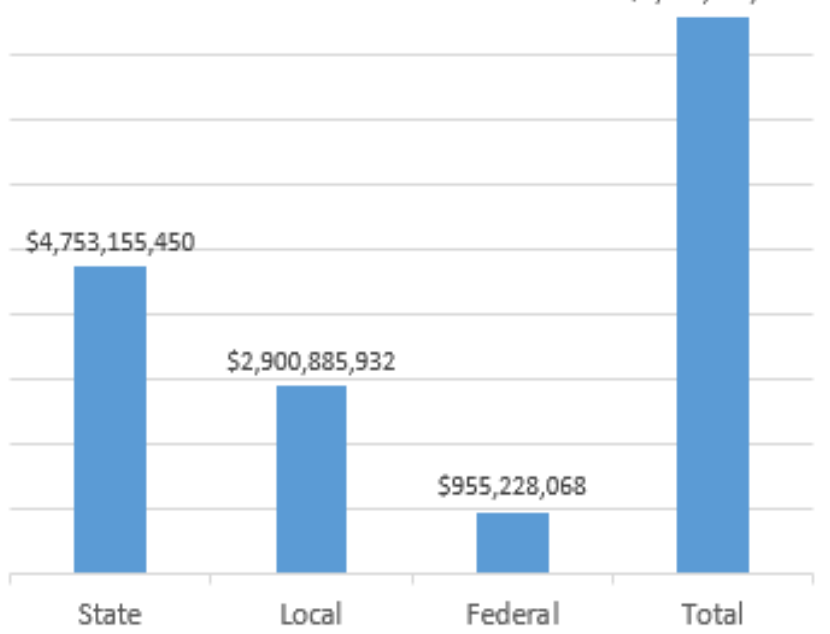

Source: See appendix Table A1 regarding 2018-2019 sources. 


\section{Aspects of Student Performance}

\section{A. Comparing K-PREP Scores, ACT Scores, and NAEP Scores}

Kentucky uses the K-PREP test to assess student progress among public school students. K-PREP has been administered every year from 2012 to 2019. This section tracks trends in the K-PREP during that time for $4^{\text {th }}$ and $8^{\text {th }}$ grade reading and math. It is compared to trends in NAEP scores for those same grades and subjects, as well as to ACT test score trends given to $11^{\text {th }}$ graders. The ACT test scores are available for each of these years. The NAEP test is given in odd years, so we make comparisons to Kentucky’s NAEP test scores for odd years from 2011 to $2019 .^{5}$

Panel (a) of Figure 6 shows the comparison of K-PREP and NAEP for grade 8 reading. For K-PREP (shown in orange), the figure plots the percent of students scoring "proficient and distinguished.” For NAEP (in blue), the percent of students scoring “proficient and advanced” is plotted. K-PREP shows a much higher percent of proficient and distinguished than NAEP shows for proficient and advanced. Moreover, K-PREP displays substantial improvement until toward the end of the time period. NAEP scoring shows little change and even some decline. This same basic pattern in repeated for each of the other comparisons; grade 8 math (panel (b)) and grade 4 reading and math (panels (c) and (d)). Panel (e) of Figure 6 plots the statewide ACT average score. It shows a slight increase, followed by a decrease, over this period.

Overall, K-PREP scoring is considerably above than that of NAEP tests. Also, K-PREP test results show substantial increases over this time frame. However, NEAP test and ACT tests indicate very little change in student outcomes.

\footnotetext{
${ }^{5}$ Appendix Table A5 presents the underlying data.
} 
Figure 6: Grade 8 Reading, K-PREP Percent Proficient and Distinguished (orange), NAEP Percent Proficient and Advanced (blue)

Panel (a)

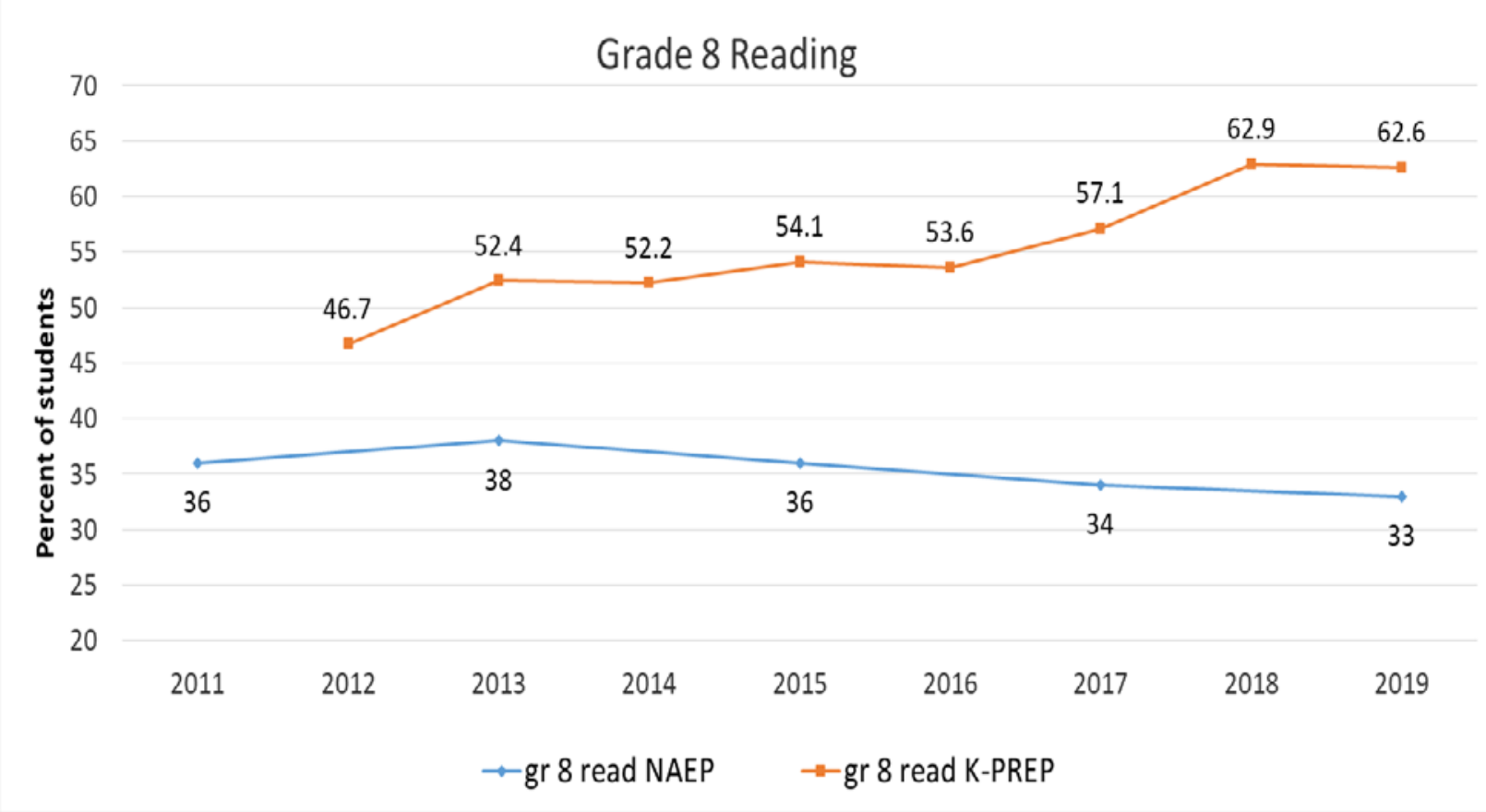

Figure 6, Panel (b)

Grade 8 Math

70

60

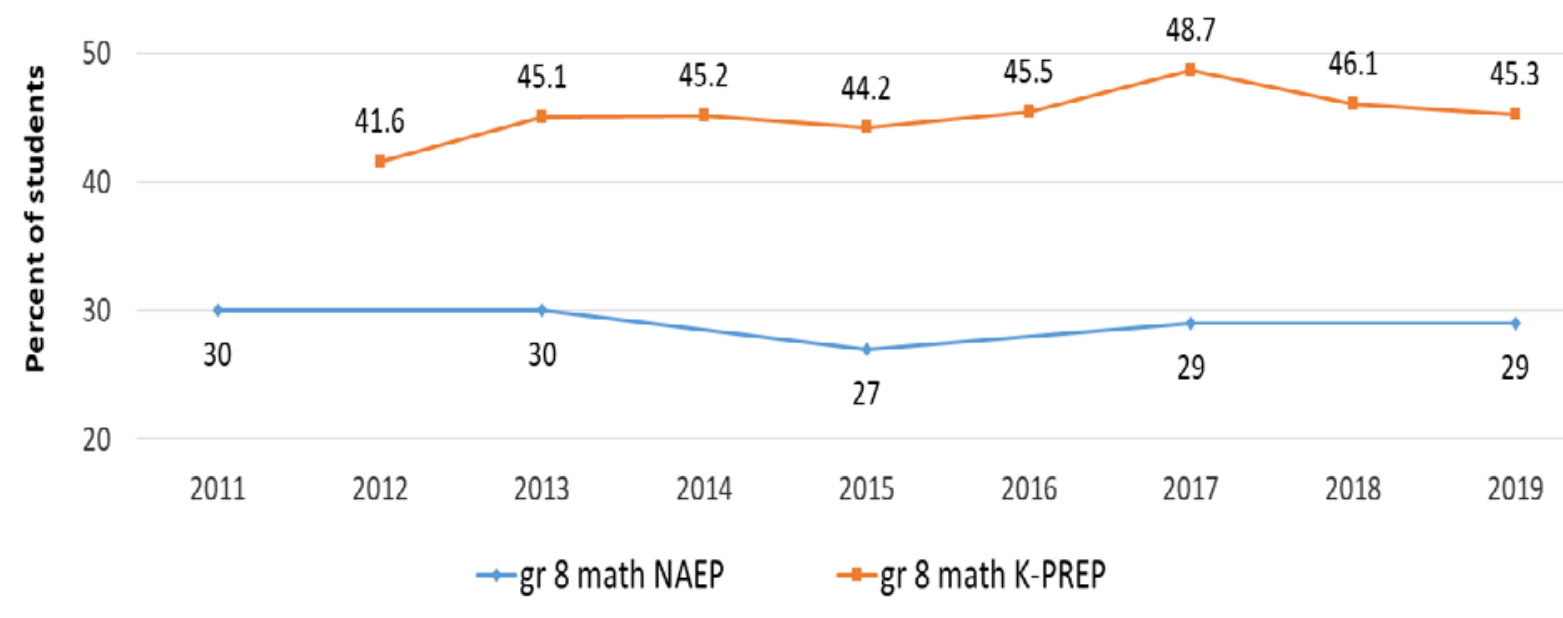


Figure 6, Panel (c)

Grade 4 Reading

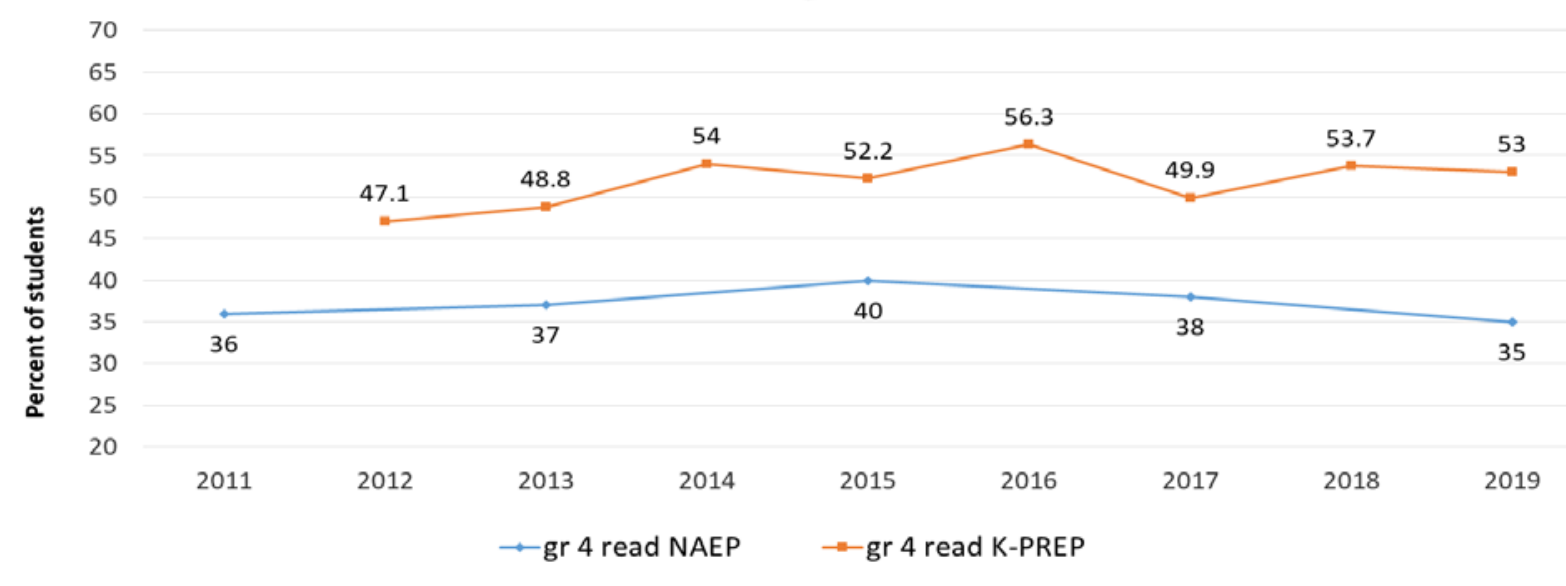

Figure 6, Panel (d)

Grade 4 Math

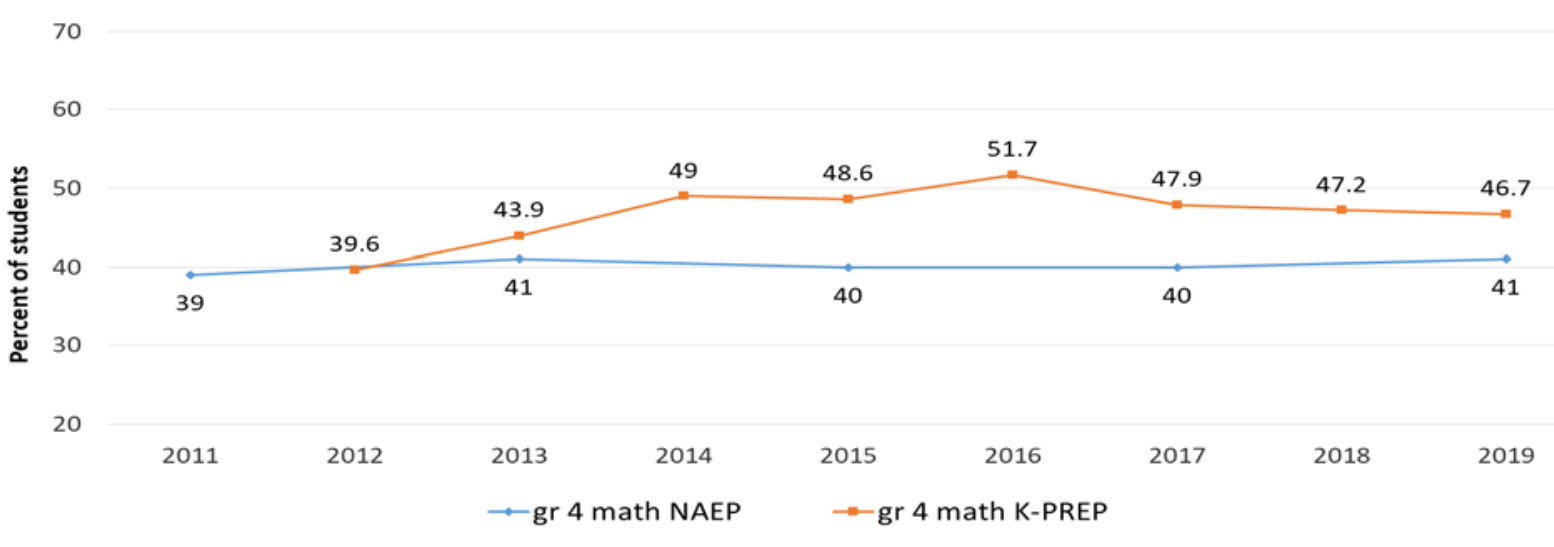

Figure 6, Panel (e)

ACT Composite Score

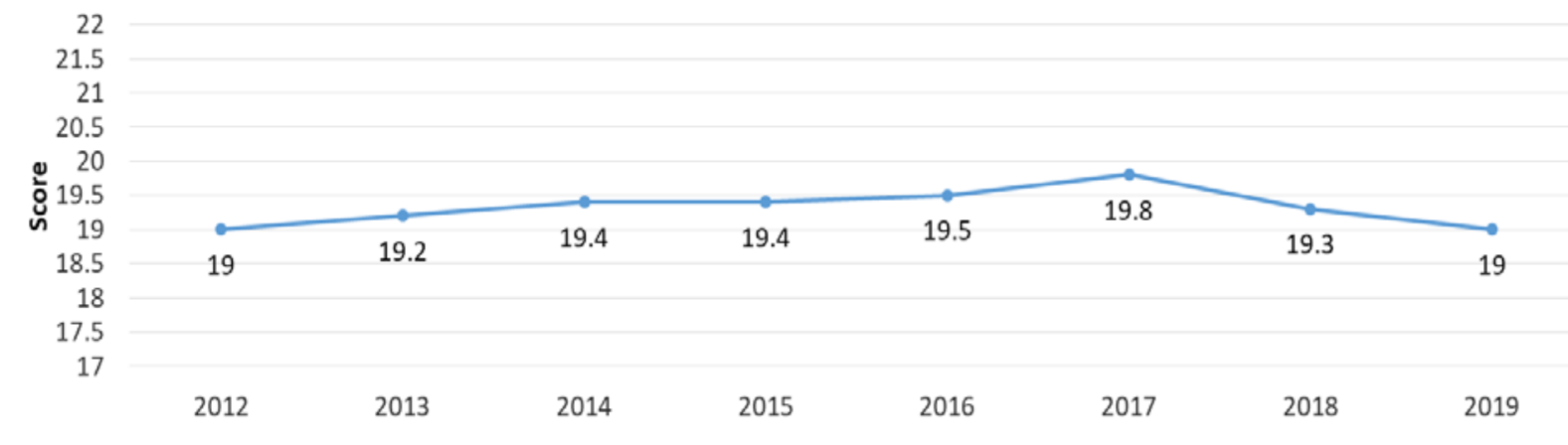




\section{B .Poorly Performing Students}

This section examines the percentages of students who score in the worst category on the K-PREP and NEAP reading and math tests in the $4^{\text {th }}$ and $8^{\text {th }}$ grades. For K-PREP, the lowest scoring category is "Novice." This is defined as: "A novice student has a minimal understanding of the Kentucky Academic Standards at grade level. ..”6 NAEP’s lowest category is "Below Basic.” Basic is defined as: “”This level denotes partial mastery of prerequisite knowledge and skills ... for ... NAEP Proficient ...”7 Below Basic fails to attain this partial mastery. Naturally, high percentages in these categories are negative outcomes.

Figure 7 shows these percentages for the 2019 tests. For grade 4 reading, 19.2\% of students are in the lowest K-PREP category and 33\% score in the lowest NAEP category. This likely means that one-fifth to one-third of $4^{\text {th }}$ graders cannot read.

Figure 7: Percent of Students in Lowest Categories, 2019

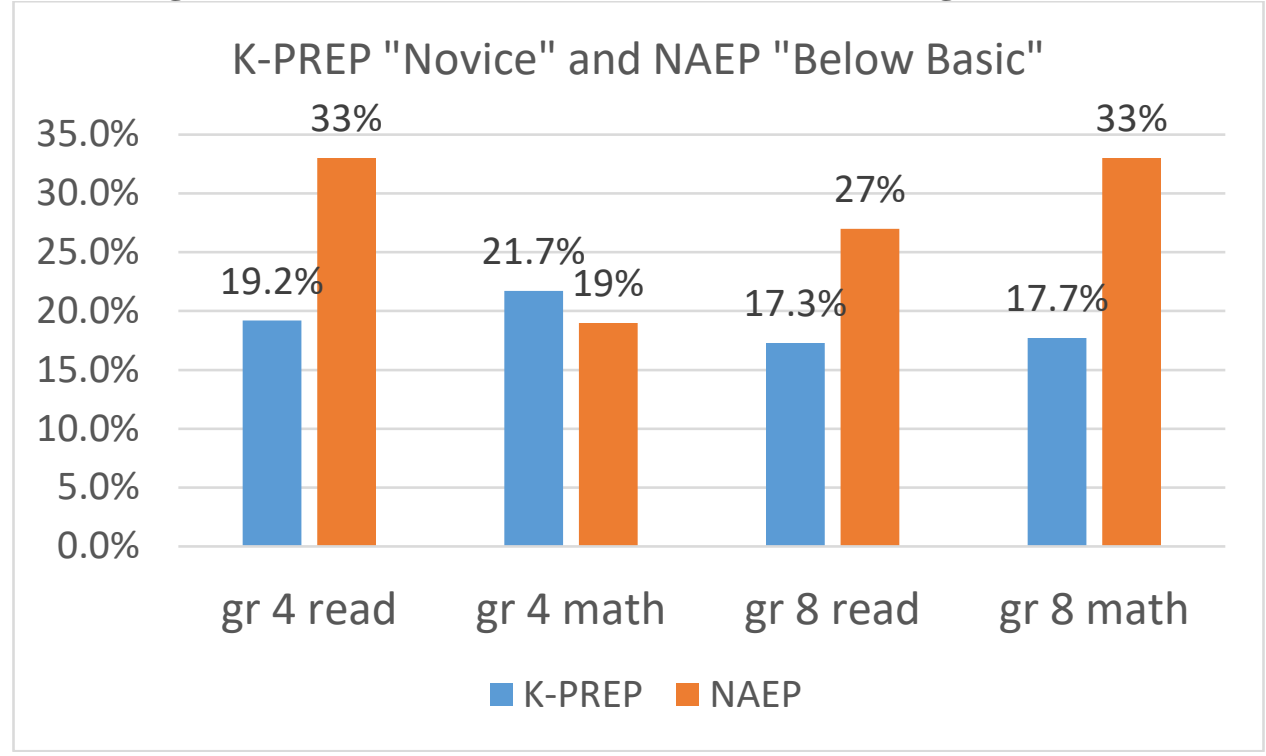

Source: See appendix Table A6.

\footnotetext{
${ }^{6}$ Definitions and discussion of the scoring categories is at https://www.kentuckyteacher.org/news/2019/10/lewis-addresses-myths-about-kentuckys-5-staraccountability-system/.

${ }^{7}$ See https://www.nagb.gov/news-and-events/news-releases/2018/release-20181119-naep-achievementlevels.html.
} 
For the other K-PREP tests, the percentages in the novice category are about the same, or a little below, as for grade 4 reading. Regarding NAEP tests, with the exception of grade 4 math, the percentages in the lowest category are much greater than for K-PREP.

\section{African Americans Students}

African American students fare even worse than average in these respects. Figure 8 shows the comparison of the percent of African Americans in the lowest category to all students for K-PREP. For grade 4 reading the percent of novice African American students is about double that for all students: $38.7 \%$ for African Americans compared to 19.2\% for all students. The comparison for the other tests is very similar.

Figure 8

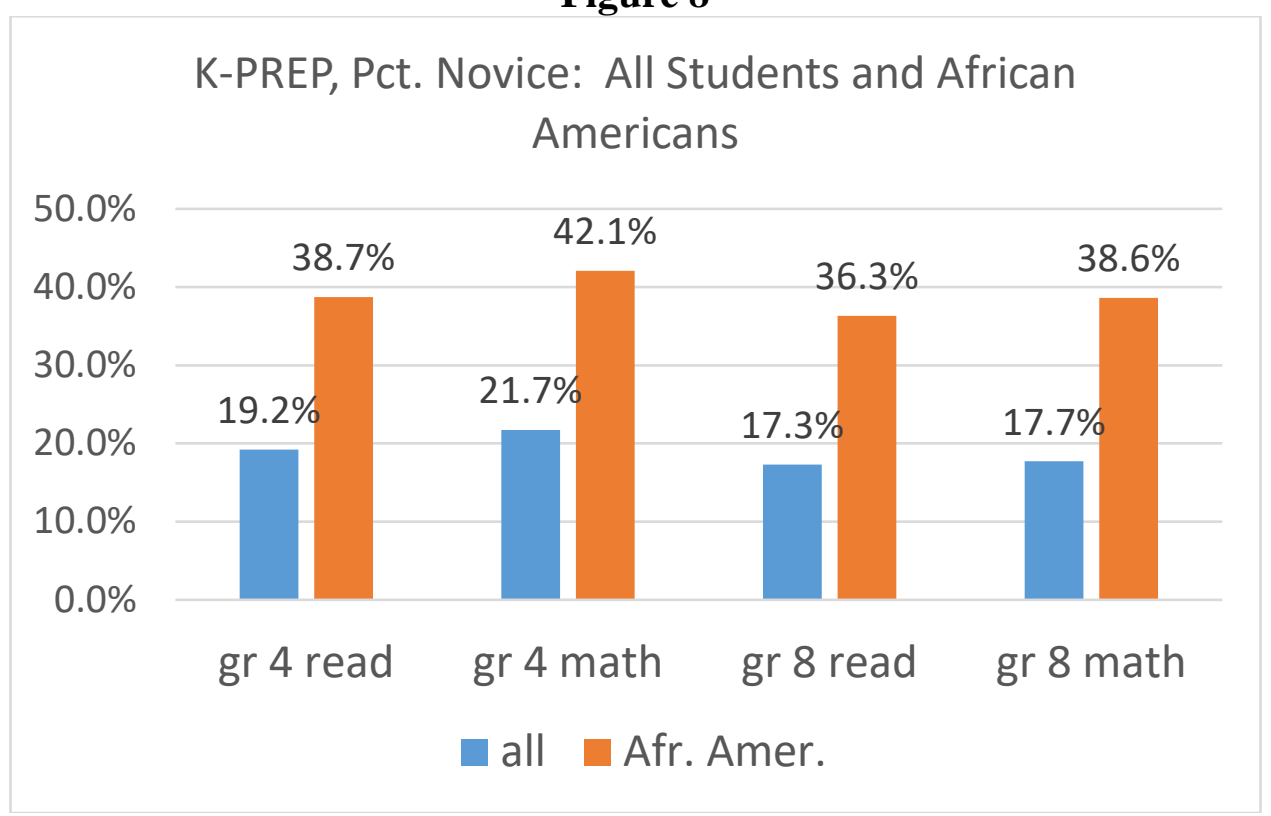

Source: See Appendix Table A7.

\section{$\underline{\text { IV. Inferences and Conclusions }}$}

The cost of Kentucky's public K-12 is high and has risen for decades. This increased cost has not been matched by improved student performance. Though there are surely some 
good public schools and programs, the system as a whole has shown little progress for the past two to three decades and, of late, exhibits declining performance. The key question for any reform is how to develop a system that generates good outcomes at reasonable cost.

The present system is dominated by funding, initiatives, and rules from Frankfort and, to some extent, from Washington. Additionally, local school districts are often political bureaucracies that have their own sets of rules and mandates. The facts and trends documented above show that this system does not work. It is important to draw upon basic economic principles to understand why this is so and how to correct it.

To attain an effective system, parties with relevant knowledge need to have decisionmaking authority. Moreover, decision makers need to be held accountable for their decisions and incentivized to make good ones. In applying these principles to schools, it is critical to recognize the heterogeneity of students, families, communities, and personal circumstances that determine the appropriate educational approach. Though there are some basics of a good education and essentials of good pedagogy, there is no single "best practice" that works for all. Thus, the goal of a good system is to enable implementation of programs that work in their specific circumstances, not to mandate particular programs for all. Those with the best knowledge of the school children are parents, teachers, and local school personnel who deal with the children nearly every day and know them and their circumstances.

Enabling the use of this knowledge is accomplished by the following: (i) Individual schools (i.e., teachers and school personnel) determine the programs, curriculum, and educational approach to take, and (ii) parents choose among schools for their children’s education, with the funding following the student. Point (i) enables schools to tailor programs to various students’ and communities’ needs. Point (ii) empowers parents to use their knowledge 
and love of their children to select among schools, and also serves as accountability and an incentive for schools to offer effective programs. Schools that fail to do so will not attract students and funding. Additionally, it is important to remove impediments to schools in opening to serve a clientele or community, and existing schools should not be artificially propped up if they cannot attract students. This helps ensure that parents have meaningful choices and that schools have to compete with one another.

This, to a large degree, is absent in the current system. Many local schools have little significant competition. Moreover, garnering more school funding typically entails lobbying Frankfort, or the local school board, rather than satisfying parents.

The forces of choice and competition noted above are powerful ones that have served us well in the provision of many critical goods and services including food, housing, clothing, fuel, automobiles, and numerous others. They also can serve us well in providing schooling. There are other items that can work to enhance choice and competition, such as increased transparency and educational-effectiveness research. However, they serve as complements to choice and competition, not substitutes for them.

There are a host of policy initiatives that move toward embracing choice and competition. They include voucher programs, educational savings accounts, charter schools, individual tax credits, and scholarship tax credits. Programs of this nature have been implemented elsewhere, have helped embrace choice and competition, and generally are shown to be effective. 


\section{$\underline{\text { Appendix }}$}

Table A1: Data Underlying Per Pupil Funding

\begin{tabular}{|c|c|c|c|c|c|c|c|c|}
\hline Year & & $\begin{array}{l}-12 \text { Funds } \\
\text { usand \$) }\end{array}$ & $\begin{array}{l}\text { Avg. Daily } \\
\text { Attendance }\end{array}$ & & $\begin{array}{l}\text { Pupil } \\
\text { Iding }\end{array}$ & $\begin{array}{l}\text { Consumer } \\
\text { Price Index }\end{array}$ & \multicolumn{2}{|c|}{$\begin{array}{l}\text { Per Pupil Funding } \\
\text { (w/o inflation) }\end{array}$} \\
\hline 1990 & $\$$ & $2,287,158$ & 569,795 & $\$$ & 4,014 & 130.7 & $\$$ & 7,852 \\
\hline 1991 & $\$$ & $2,729,811$ & 569,713 & $\$$ & 4,792 & 136.2 & $\$$ & 8,994 \\
\hline 1992 & $\$$ & $2,939,351$ & 574,226 & $\$$ & 5,119 & 140.3 & $\$$ & 9,328 \\
\hline 1993 & $\$$ & $3,071,172$ & 579,446 & $\$$ & 5,300 & 144.5 & $\$$ & 9,377 \\
\hline 1994 & $\$$ & $3,194,404$ & 578,020 & $\$$ & 5,526 & 148.2 & $\$$ & 9,534 \\
\hline 1995 & $\$$ & $3,240,926$ & 572,952 & $\$$ & 5,657 & 152.4 & $\$$ & 9,489 \\
\hline 1996 & $\$$ & $3,492,890$ & 571,934 & $\$$ & 6,107 & 156.9 & $\$$ & 9,951 \\
\hline 1997 & $\$$ & $3,794,129$ & 570,431 & $\$$ & 6,651 & 160.5 & $\$$ & 10,595 \\
\hline 1998 & $\$$ & $3,932,068$ & 569,694 & $\$$ & 6,902 & 163.0 & $\$$ & 10,826 \\
\hline 1999 & $\$$ & $4,210,793$ & 568,603 & $\$$ & 7,406 & 166.6 & $\$$ & 11,364 \\
\hline 2000 & $\$$ & $4,330,619$ & 565,693 & $\$$ & 7,655 & 172.2 & $\$$ & 11,366 \\
\hline 2001 & $\$$ & $4,509,893$ & 564,198 & $\$$ & 7,993 & 177.1 & $\$$ & 11,539 \\
\hline 2002 & $\$$ & $4,650,146$ & 566,451 & $\$$ & 8,209 & 179.9 & $\$$ & 11,666 \\
\hline 2003 & $\$$ & $4,764,253$ & 569,538 & $\$$ & 8,365 & 184.0 & $\$$ & 11,623 \\
\hline 2004 & $\$$ & $5,077,772$ & 570,911 & $\$$ & 8,894 & 188.9 & $\$$ & 12,037 \\
\hline 2005 & $\$$ & $5,379,257$ & 574,380 & $\$$ & 9,365 & 195.3 & $\$$ & 12,260 \\
\hline 2006 & $\$$ & $5,909,930$ & 580,937 & $\$$ & 10,173 & 201.6 & $\$$ & 12,901 \\
\hline 2007 & $\$$ & $6,141,245$ & 583,102 & $\$$ & 10,532 & 207.342 & $\$$ & 12,986 \\
\hline 2008 & $\$$ & $6,561,268$ & 585,775 & $\$$ & 11,201 & 215.303 & $\$$ & 13,300 \\
\hline 2009 & $\$$ & $6,641,128$ & 585,556 & $\$$ & 11,342 & 214.537 & $\$$ & 13,515 \\
\hline 2010 & $\$$ & $6,873,286$ & 587,102 & $\$$ & 11,707 & 218.056 & $\$$ & 13,726 \\
\hline 2011 & $\$$ & $6,993,349$ & 593,323 & $\$$ & 11,787 & 224.939 & $\$$ & 13,396 \\
\hline 2012 & $\$$ & $7,086,717$ & 594,440 & $\$$ & 11,922 & 229.594 & $\$$ & 13,275 \\
\hline 2013 & $\$$ & $7,120,960$ & 618,774 & $\$$ & 11,508 & 232.957 & $\$$ & 12,630 \\
\hline 2014 & $\$$ & $7,137,145$ & 622,088 & $\$$ & 11,473 & 236.736 & $\$$ & 12,390 \\
\hline 2015 & $\$$ & $7,453,976$ & 617,642 & $\$$ & 12,068 & 237.017 & $\$$ & 13,018 \\
\hline 2016 & $\$$ & $7,634,758$ & 618,606 & $\$$ & 12,342 & 240.007 & $\$$ & 13,147 \\
\hline 2017 & $\$$ & $7,782,860$ & 616,218 & $\$$ & 12,629 & 245.120 & $\$$ & 13,172 \\
\hline 2018 & $\$$ & $8,433,367$ & 614,301 & $\$$ & 14,068 & 251.107 & $\$$ & 13,977 \\
\hline 2019 & $\$$ & $8,609,269$ & 609,955 & $\$$ & 14,249 & 255.657 & $\$$ & 14,115 \\
\hline
\end{tabular}

Sources: Funding and attendance data, 1987-2017: https://nces.ed.gov/programs/digest/.

Funding data, 2018-2019:

https://education.ky.gov/districts/FinRept/Pages/Fund\%20Balances,\%20Revenues\%20and\%20Expendit ures, \%20Chart\%20of\%20Accounts,\%20Indirect\%20Cost\%20Rates\%20and\%20Kev\%20Financial\%20Indica tors.aspx.

Attendance data, 2018-2019: https://education.ky.gov/districts/enrol/Pages/Superintendents-AnnualAttendance-Report-(SAAR).aspx.

Consumer Price Index: https://www.bls.gov/data/. 
Table A2: Kentucky $4^{\text {th }}$ and $8^{\text {th }}$ Grade Reading and Math Average NAEP Scores

\begin{tabular}{|c|c|c|c|c|}
\hline Year & $\begin{array}{c}\text { NAEP Grade } 4 \\
\text { Reading }\end{array}$ & $\begin{array}{c}\text { NAEP Grade } 4 \\
\text { Math }\end{array}$ & $\begin{array}{c}\text { NAEP Grade } 8 \\
\text { Reading }\end{array}$ & $\begin{array}{c}\text { NAEP Grade } 8 \\
\text { Math }\end{array}$ \\
\hline 1990 & & & & 257 \\
\hline \multicolumn{5}{|l|}{1991} \\
\hline 1992 & 213 & 215 & & 262 \\
\hline \multicolumn{5}{|l|}{1993} \\
\hline 1994 & 212 & & & \\
\hline \multicolumn{5}{|l|}{1995} \\
\hline 1996 & & 220 & & 267 \\
\hline \multicolumn{5}{|l|}{1997} \\
\hline 1998 & 218 & & 262 & \\
\hline \multicolumn{5}{|l|}{1999} \\
\hline 2000 & & 219 & & 270 \\
\hline \multicolumn{5}{|l|}{2001} \\
\hline 2002 & 219 & & 265 & \\
\hline 2003 & 219 & 229 & 266 & 274 \\
\hline \multicolumn{5}{|l|}{2004} \\
\hline 2005 & 220 & 231 & 264 & 274 \\
\hline \multicolumn{5}{|l|}{2006} \\
\hline 2007 & 222 & 235 & 262 & 279 \\
\hline \multicolumn{5}{|l|}{2008} \\
\hline 2009 & 226 & 239 & 267 & 279 \\
\hline \multicolumn{5}{|l|}{2010} \\
\hline 2011 & 225 & 241 & 269 & 282 \\
\hline \multicolumn{5}{|l|}{2012} \\
\hline 2013 & 224 & 241 & 270 & 281 \\
\hline \multicolumn{5}{|l|}{2014} \\
\hline 2015 & 228 & 242 & 268 & 278 \\
\hline \multicolumn{5}{|l|}{2016} \\
\hline 2017 & 224 & 239 & 265 & 278 \\
\hline \multicolumn{5}{|l|}{2018} \\
\hline 2019 & 221 & 239 & 263 & 278 \\
\hline
\end{tabular}

Source: https://www.nationsreportcard.gov/ndecore/xplore/NDE. 
Table A3: Source Websites for Private School Tuition Rates

\begin{tabular}{|c|c|}
\hline$\underline{\text { School }}$ & Website \\
\hline $\begin{array}{l}\text { Christian Academy of } \\
\text { Carrollton }\end{array}$ & $\begin{array}{l}\text { http://nebula.wsimg.com/e143cf9dfa15997df3ec9148fab43dd8? } \\
\text { AccessKeyld=1343D5B4ADF35A2819A0\&disposition=0\&alloworigin=1 }\end{array}$ \\
\hline $\begin{array}{l}\text { Christian Fellowship School } \\
\text { (Benton) }\end{array}$ & $\begin{array}{l}\text { http://www.christianfellowshipschool.org/editoruploads/files/Fee Sch } \\
\text { edule 20-21.pdf }\end{array}$ \\
\hline $\begin{array}{l}\text { Cornerstone Christian Academy } \\
\text { (London) }\end{array}$ & https://www.cornerstoneky.com/tuition \\
\hline St. Joseph Academy (Walton) & $\begin{array}{l}\text { https://sjawalton.com/wp-content/uploads/2020/04/2020-2021- } \\
\text { Tuition-Rates.pdf }\end{array}$ \\
\hline $\begin{array}{l}\text { Foundation Christian Academy } \\
\text { (Bowling Green) }\end{array}$ & $\begin{array}{l}\text { http://www.fcafalcons.com/wp-content/uploads/2020/03/2020-2021- } \\
\text { Tuition-Fees.jpg }\end{array}$ \\
\hline $\begin{array}{l}\text { Highlands Latin School } \\
\text { (Louisville) }\end{array}$ & https://thelatinschool.org/admissions/tuitionandfees/ \\
\hline Christ the King (Lexington) & $\begin{array}{l}\text { https://ctkschool.net/application/files/1015/8284/0250/CKS Tuition I } \\
\text { nformation 2020-21.pdf }\end{array}$ \\
\hline Lexington Christian Academy & http://www.lexingtonchristian.org/admissions/tuition.cfm \\
\hline $\begin{array}{l}\text { Northern Kentucky Montessori } \\
\text { Academy }\end{array}$ & $\begin{array}{l}\text { https://drive.google.com/file/d/1jN5J5sO 1VuJ4qZINgBDh3A8aBll7 ur } \\
\text { Lview }\end{array}$ \\
\hline The Lexington School & https://www.thelexingtonschool.org/tuition-schedule \\
\hline Somerset Christian School & https://somersetchristian.com/tuition-and-financial-aid/ \\
\hline Lexington Latin School & http://www.lexingtonlatinschool.com/admissions.html \\
\hline Frankfort Christian Academy & $\begin{array}{l}\text { https://filecabinet9.eschoolview.com/A3358F45-40E0-4D3C-85F7- } \\
\text { C9AE0867FBBE/2020 2021TuitionandFees.pdf }\end{array}$ \\
\hline $\begin{array}{l}\text { Bethlehem High School } \\
\text { (Bardstown) }\end{array}$ & $\begin{array}{l}\text { https://www.bethlehemhigh.org/apps/pages/index.jsp?uREC ID =1175 } \\
\text { 215\&type=d\&pREC ID }=1423513\end{array}$ \\
\hline Newport Central Catholic High & $\begin{array}{l}\text { https://static1.squarespace.com/static/586fb6c5414fb5bea0aa8fe5/t/ } \\
\text { 5ecd31592dd571390ca7a028/1590505818029/2020-2021+Tuition.pdf }\end{array}$ \\
\hline $\begin{array}{l}\text { Calvary Christian School } \\
\text { (Covington) }\end{array}$ & $\begin{array}{l}\text { https://s3.amazonaws.com/media.cloversites.com/5a/5a66b655- } \\
\text { 92ba-4de6-a494-7c30cd6f3924/documents/Tuition 2020- } \\
219 \text { month.pdf }\end{array}$ \\
\hline Trinity Christian (Lexington) & https://www.trinitylex.org/tuition-financial-aid \\
\hline $\begin{array}{l}\text { Lexington Catholic High } \\
\text { School }\end{array}$ & https://www.lexingtoncatholic.com/apps/pages/tuitionassistance \\
\hline St. Xavier (Louisville) & https://www.saintx.com/admissions/tuition-information \\
\hline Sayre School (Lexington) & https://www.sayreschool.org/page.cfm?p=4415 \\
\hline
\end{tabular}


Table A4: 2018-2019 K-12 Expenditure Categories

\begin{tabular}{|c|c|c|}
\hline Expenditure Category & Amount & Percent \\
\hline Instruction & $\$ 4,513,569,932$ & 53.27 \\
\hline $\begin{array}{c}\text { Student Support } \\
\text { Services }\end{array}$ & $\$ 381,850,510$ & 4.51 \\
\hline $\begin{array}{l}\text { Instruction Staff } \\
\text { Support Services }\end{array}$ & $\$ 414,290,938$ & 4.89 \\
\hline District Admin. & $\$ 167,969,572$ & 1.98 \\
\hline School Admin. & $\$ 461,355,976$ & 5.44 \\
\hline $\begin{array}{c}\text { Business Support } \\
\text { Services }\end{array}$ & $\$ 212,709,902$ & 2.51 \\
\hline Plant Operations & $\$ 665,226,430$ & 7.85 \\
\hline Pupil Transportation & $\$ 476,292,863$ & 5.62 \\
\hline Other Support Services & $\$ 246,861$ & 0.00 \\
\hline Food Service & $\$ 480,986,580$ & 5.68 \\
\hline Day Care Operations & $\$ 68,797$ & 0.00 \\
\hline Community Services & $\$ 72,368,456$ & 0.85 \\
\hline $\begin{array}{l}\text { Adults Education } \\
\text { Operations }\end{array}$ & $\$ 324,852$ & 0.00 \\
\hline Other Non-Instruction & $\$ 20,703$ & 0.00 \\
\hline $\begin{array}{c}\text { Facilities Land/Site } \\
\text { Acquisition }\end{array}$ & $\$ 472,353$ & 0.01 \\
\hline $\begin{array}{l}\text { Facilities Land } \\
\text { Improvement }\end{array}$ & $\$ 485,833$ & 0.01 \\
\hline $\begin{array}{c}\text { Facilities Architecture } \\
\text { And Engineering }\end{array}$ & $\$ 4,815,799$ & 0.06 \\
\hline $\begin{array}{c}\text { Facilities Education } \\
\text { Specification }\end{array}$ & $\$ 20,591$ & 0.00 \\
\hline $\begin{array}{c}\text { Facilities Building } \\
\text { Acquisition \& } \\
\text { Construction }\end{array}$ & $\$ 3,500$ & 0.00 \\
\hline $\begin{array}{c}\text { Facilities Site } \\
\text { Improvement }\end{array}$ & $\$ 567,456$ & 0.01 \\
\hline $\begin{array}{c}\text { Facilities Building } \\
\text { Improvement }\end{array}$ & $\$ 473,051$ & 0.01 \\
\hline $\begin{array}{c}\text { Other Facilities } \\
\text { Acquisition }\end{array}$ & $\$ 0$ & 0.00 \\
\hline Debt Service & $\$ 619,238,826$ & 7.31 \\
\hline Total Expenses & $\$ 8,473,359,767$ & 100.00 \\
\hline
\end{tabular}

Source: https://education.ky.gov/districts/FinRept/Pages/Fund\% 20Balances,\%20Revenues\%20and\%20Expenditures,\%20Chart\%20of\%20Accounts,\%20Indirect\%20Cost \%20Rates\%20and\%20Key\%20Financial\%20Indicators.aspx.

Note: Fund transfers are not included in table. 
Table A5: NAEP Percentages Proficient and Advances; K-PREP Percentages Proficient and Distinguished; ACT Scores

\begin{tabular}{|c|c|c|c|c|c|c|c|c|c|}
\hline & \multicolumn{2}{|c|}{ Grade 4 Reading } & \multicolumn{2}{|c|}{ Grade 4 Math } & \multicolumn{2}{|c|}{ Grade 8Reading } & \multicolumn{2}{|c|}{ Grade 8Math } & \\
\hline Year $P$ & $\begin{array}{c}\text { NAEP Pct. } \\
\text { Proficient \& Adv. }\end{array}$ & $\begin{array}{c}\text { K-PREP Pct. } \\
\text { Proficient \& Disting. }\end{array}$ & $\begin{array}{c}\text { NAEP Pct. } \\
\text { Proficient \& Adv. }\end{array}$ & $\begin{array}{c}\text { K-PREP Pct. } \\
\text { Proficient \& Disting. }\end{array}$ & $\begin{array}{c}\text { NAEP Pct. } \\
\text { Proficient \& Adv. }\end{array}$ & $\begin{array}{c}\text { K-PREP Pct. } \\
\text { Proficient \& Disting. }\end{array}$ & $\begin{array}{c}\text { NAEP Pct. } \\
\text { Proficient \&Adv. }\end{array}$ & $\begin{array}{c}\text { K-PREP Pct. } \\
\text { Proficient \& Disting. }\end{array}$ & ACTScore \\
\hline 2011 & 36 & & 39 & & 36 & & 30 & & \\
\hline 2012 & & 47.1 & & 39.6 & & 46.7 & & 41.6 & 19 \\
\hline 2013 & 37 & 48.8 & 41 & 43.9 & 38 & 52.4 & 30 & 45.1 & 19.2 \\
\hline 2014 & & 54 & & 49 & & 52.2 & & 45.2 & 19.4 \\
\hline 2015 & 40 & 52.2 & 40 & 48.6 & 36 & 54.1 & 27 & 44.2 & 19.4 \\
\hline 2016 & & 56.3 & & 51.7 & & 53.6 & & 45.5 & 19.5 \\
\hline 2017 & 38 & 49.9 & 40 & 47.9 & 34 & 57.1 & 29 & 48.7 & 19.8 \\
\hline 2018 & & 53.7 & & 47.2 & & 62.9 & & 46.1 & 19.3 \\
\hline 2019 & 35 & 53 & 41 & 46.7 & 33 & 62.6 & 29 & 45.3 & 19 \\
\hline
\end{tabular}

Sources: https://applications.education.ky.gov/SRC/DataSets.aspx,

https://openhouse.education.ky.gov/Home/SRCData

https://www.nationsreportcard.gov/ndecore/xplore/NDE.

Table A6: NAEP Percentages Below Basic; K-PREP Percentages Novice, All Students

\begin{tabular}{|r|c|c|c|c|c|c|c|c|}
\hline & \multicolumn{2}{|c|}{ Grade 4Reading } & \multicolumn{2}{c|}{ Grade 4Math } & \multicolumn{2}{c|}{ Grade 8Reading } & \multicolumn{2}{|c|}{ Grade 8Math } \\
\hline Year & $\begin{array}{c}\text { NAEP Pct. } \\
\text { Below Basic }\end{array}$ & $\begin{array}{c}\text { K-PREP Pct. } \\
\text { Novice }\end{array}$ & $\begin{array}{c}\text { NAEP Pct. } \\
\text { Below Basic }\end{array}$ & $\begin{array}{c}\text { K-PREP Pct. } \\
\text { Novice }\end{array}$ & $\begin{array}{c}\text { NAEP Pct. } \\
\text { Below Basic }\end{array}$ & $\begin{array}{c}\text { K-PREP Pct. } \\
\text { Novice }\end{array}$ & $\begin{array}{c}\text { NAEP Pct. } \\
\text { Below Basic }\end{array}$ & $\begin{array}{c}\text { K-PREP Pct. } \\
\text { Novice }\end{array}$ \\
\hline 2011 & 28 & & 15 & & 21 & & 28 & \\
\hline 2012 & & 24.9 & & 21.5 & & 22.1 & & 20.8 \\
\hline 2013 & 29 & 26.9 & 16 & 23.2 & 20 & 24.4 & 29 & 15.9 \\
\hline 2014 & & 20.5 & & 18.5 & & 23.8 & & 16.5 \\
\hline 2015 & 25 & 18.8 & 16 & 20.4 & 22 & 21.8 & 32 & 15.1 \\
\hline 2016 & & 19.7 & & 17.5 & & 23.3 & & 17.6 \\
\hline 2017 & 30 & 21.7 & 20 & 17.9 & 25 & 25.8 & 35 & 18 \\
\hline 2018 & & 18.6 & & 21.4 & & 23 & & 17 \\
\hline 2019 & 33 & 19.2 & 19 & 21.7 & 27 & 21.5 & 33 & 17.7 \\
\hline
\end{tabular}

Source: See Table A5. 
Table A7: NAEP Percentages Below Basic; K-PREP Percentages Novice, African Americans

\begin{tabular}{|c|c|c|c|c|c|c|c|c|}
\hline & \multicolumn{2}{|c|}{ Grade 4 Reading } & \multicolumn{2}{|c|}{ Grade 4Math } & \multicolumn{2}{|c|}{ Grade 8Reading } & \multicolumn{2}{|c|}{ Grade 8Math } \\
\hline Year & $\begin{array}{l}\text { NAEP Pct. } \\
\text { Below Basic }\end{array}$ & $\begin{array}{l}\text { K-PREP Pct. } \\
\text { Novice }\end{array}$ & $\begin{array}{c}\text { NAEP Pct. } \\
\text { Below Basic }\end{array}$ & $\begin{array}{l}\text { K-PREP Pct. } \\
\text { Novice }\end{array}$ & $\begin{array}{c}\text { NAEP Pct. } \\
\text { Below Basic }\end{array}$ & $\begin{array}{l}\text { K-PREP Pct. } \\
\text { Novice }\end{array}$ & $\begin{array}{l}\text { NAEP Pct. } \\
\text { Below Basic }\end{array}$ & $\begin{array}{l}\text { K-PREP Pct. } \\
\text { Novice }\end{array}$ \\
\hline 2011 & 48 & & 31 & & 42 & & 53 & \\
\hline 2012 & & 43.4 & & 38.8 & & 48.3 & & 36.6 \\
\hline 2013 & 52 & 48.7 & 35 & 38.9 & 44 & 43.4 & 51 & 31 \\
\hline 2014 & & 39.5 & & 34.9 & & 37.2 & & 32.4 \\
\hline 2015 & 41 & 36.3 & 32 & 35.2 & 42 & 38.5 & 57 & 30.2 \\
\hline 2016 & & 39.9 & & 34.4 & & 41.6 & & 37 \\
\hline 2017 & 53 & 43.4 & 45 & 35.7 & 46 & 45 & 63 & 37 \\
\hline 2018 & & 38 & & 43.8 & & 36.5 & & 36 \\
\hline 2019 & 57 & 38.7 & 37 & 42.1 & 51 & 36.3 & 57 & 38.6 \\
\hline
\end{tabular}

Sources: See Table A5. 